\title{
Dividend Policy, Firms' Characteristics and the Impact on the Southeast Asian Firms' Value
}

\author{
Arni Surwanti ${ }^{1 *}$, Wihandaru Sotya Pamungkas ${ }^{1}$ \\ ${ }^{1}$ Universitas Muhammadiyah Yogyakarta \\ *Corresponding author. Email: arni_surwanti@umy.ac.id
}

\begin{abstract}
This research aims to analyze the factors determining the dividend policy of the Southeast Asian non-financial corporate sectors. In this research, the dividend policy of firms in Southeast Asia follows more closely the predictions of ModiglianiMiller theory, that dividend policy does not give impact to the firms' value, but the firms' characteristics include investment decision that supports to the firms' value. This research is verification research that aims to explain the causal relationship between the variables through hypothesis testing. The samples were taken by specifying multiple criteria. The criteria required in this research are: First, these companies are included in the non-financial industries. Second, the companies have been listed on the Capital Market in the selected countries in Southeast Asian Capital Market between 2000-2015. Third, from 2000 to 2015, the companies distributed the cash dividend. The study used panel data of companies listed in the capital market in selected countries in Southeast Asia. This study analyzes the dividend policy of non-financial companies in selected countries in Southeast Asia. This study showed that In Indonesia, the dividend payment was determined by the company's size, while in the Philippines, it was determined by the condition of the company's liquidity. Companies in five countries consistently showed that size was a significant factor affecting firm value. This finding implied that investors would be better off investing in large companies because the value tended to increase and, of course, would impact the welfare of shareholders. This study confirmed that the dividend payment showed a positive impact on the firm value in Malaysia and Philipina. Companies in the Philippines showed that dividends significantly affected firm value. Meanwhile, dividends were significantly influenced by company liquidity. Based on this study's results in the Philippines, dividend policy mediated the effect of liquidity on firm value.
\end{abstract}

Keywords: Dividend Decision, Firm's Characteristics, Firms' Value.

\section{INTRODUCTION}

The company's objective in financial management is to maximize the value of the company. Firm value is a market value because the market value can provide maximum prosperity for shareholders if their share price increases. Various policies are taken by management to increase company value, one of which is dividend policy [4]. The optimal dividend policy is a dividend policy that can balance current dividends and future growth to maximize the company's stock price. The value of companies that have gone public in the capital market is reflected in the price of the company's shares, while the meaning of the value of companies that have not gone public, the value realized if the company will be sold.

Every company listed on the capital market included in Southeast Asian firms wants the price of shares to be sold to have a high potential price and attract investors to buy them. It is because the higher the stock price, the higher the value of the company. The company value, indicated by a high Price to Book Value (PBV), is the desire of company owners or is the goal of business companies at this time because it will increase the prosperity of shareholders or stockholder wealth maximization [4] state that company value is the price that prospective buyers are willing to pay if the company is sold. Firm value can describe the state of the company. With good company value, the company will be viewed favorably by potential investors, and vice versa. High company value indicates good company performance [15] [16].

The higher the company value, the greater the prosperity the company owner will receive. For companies that issue shares on the capital market, the price of shares traded on the stock exchange is an indicator of company value. The company value is significant because the high prosperity of shareholders will follow high company value. A high company value is company owners' desire because a high value shows that the 
shareholder's prosperity is also high. There are two significant groups of opinions which state that dividends affect firm value. Modigliani and Miller [4] state that dividend payments do not affect firm value, but investment policies affect firm value. Meanwhile, Bird In The Hand Theory and Signaling theory states that dividend policy affects the company's value because it provides certainty of income for shareholders and signals the prospects that the company will have adequate financial performance in the future. The increase in firm value can be determined by several factors besides dividend payments, including managerial ownership, financial leverage, profitability, company size, liquidity, profitability, or other factors that influence firm value.

Company growth and dividend policy are two matters that the company wants to achieve but have different goals. Companies that are growing will undoubtedly increase their investment for the future, taken from retained earnings, but on the other hand, shareholders investors want the profit to be distributed in the form of dividends. Dividend policy is a policy of the management of a business entity/company in determining the profit available to shareholders to be distributed in the form of dividends or retained earnings to finance the company's investment in the future. In the past, dividend policies were often debated by shareholders and management. In general, shareholders want more dividends. If the company decides not to distribute dividends, the retained earnings will be a source of internal funding. The capacity of internal sources of funds increases so that it will strengthen the owner's equity position because the company is less dependent on external sources of funds. In determining the distribution of dividends, companies need to consider various factors that affect the dividend policy itself.

Various factors influence dividend policy. Several previous studies have shown that dividend policy was influenced by several determinants, including liquidity, profitability, indebtedness, tangibility, investment opportunities, market ratio, company's size, company's age, ownership structure [15]. Jung and Mun [16] focus on foreign investors' role in this process of dividend policy. This research use panel data on 2,036 publicly traded Japanese firms from 1990 to 2005. This research showed that foreign investors' pressure increased dividends by Japanese firms directly and indirectly. The characteristic of stockholders could also determine the dividend payment. Crain (2016) showed that higher institutional ownership caused firms to pay more dividends. Research of Ucar [26] empirically investigated whether geographical variations in the local culture, as proxied by local religion, affecting dividend demand and corporating dividend policy for a large sample of US firms. This research supported Clientele Effect Theory that firms located in Protestant counties were more likely to be dividend payers, initiate dividends, and have higher dividend yields, while firms located in Catholic counties were less likely to be dividend payers and have a lower dividend. Meanwhile, economic conditions could also determine dividend policy. Byoun and $\mathrm{Zu}$ [8] examined the economic crisis, showing that when a company could get a loan, it would increase its dividend payment ability, and additional investment in working capital would reduce the company's ability to pay dividends. Meanwhile, dividend policy could be influenced by several factors, company characteristics and macroeconomic conditions. [15] [16]

This work aims to analyze the factors that determined the dividend policy of non-financial corporate sectors in the Southeast Asian Countries. This study also has tested the dividend policy mediate the firms' characteristics to the firms' value. This research is verification research that aims to explain the causal relationship between the variables through hypothesis testing. The samples are taken by specifying multiple criteria. The criteria required in this research are: First, these companies were included in the non-financial industries. Second, the companies had been listed on the Capital Market in the selected countries in Southeast Asian Capital Market between 2000-2015. Third, in the period 2000 through 2015, the companies paid a cash dividend.

Previews researchers only did study capital structure decision in one country. This study attempts to examine the capital structure decision of non-financial companies in selected countries in Southeast Asia. This study analyzes the determinant of dividend policy, and this study also tries to prove that dividend policy mediates the firms' characteristics to the companies' value. This study observed the Bird in hand and signaling theory. There is a variation of dividend policy of the firms in Southeast Asia countries. The dividend policy changes from time to time due to changes in firms' characteristics and macroeconomic factors. This study also shows the dividend policy and the other firms' characteristics impact the firms' value. This research also tested the dividend decision mediating the firm's characteristics and macroeconomics factors to the firms' value.

\section{THE DETERMINANT OF DIVIDEND POLICY AND FIRMS 'VALUE}

Investors consider the firms' value when investing. A firms' value is the present value of future income (future free cash flow) based on a financial perspective. Dividend policy and other company characteristics can influence firm value.

Modigliani and Miller in [4] told that dividend policy would not impact the firms' value, but investment policy would impact shareholder wealth. The theory of a bird in the hand and signaling shows that dividends can increase 
firm value. Based on the theory of a bird in the hand, companies that distribute dividends provide certainty of income for current investors. Based on the signaling theory, dividend payments imply that the company's future performance will be useful because it tends to maintain dividend payments in the future. Dividend signaling theory was first coined by Bhattacharya (1979) [4], underlying the assumption that the announcement of cash dividend changes has the information content resulting in stock price reactions. This theory explains that investors' information about cash dividends is a signal of the company's prospects. This assumption is caused by asymmetric information between managers and investors, so that investors use dividend policy as a signal about the company's prospects. If there is an increase in dividends, it will be considered a positive signal, meaning that the company has good prospects, causing a positive stock price reaction.

Conversely, suppose there is a decrease in dividends. In that case, it will be considered a negative signal, which means that the company has not very good prospects, resulting in an adverse stock price reaction: finance, profitability, company size, liquidity and macroeconomic conditions [17]. Investors use dividend policy as a signal about the company's prospects. If there is an increase in dividends, it will be considered a positive signal, meaning that the company has good prospects, causing a positive stock price reaction. A higher dividend increases the market value of the share and vice versa. Shareholders prefer the current dividend to the future income, so the dividend is considered an essential determining factor of the shareholders' wealth [5]. Firm value in the property, real estate, and building construction sectors listed on the Indonesia Stock Exchange is proxied by Price to Book Value (PBV), determined by profitability and institutional ownership. Setiadharma and Machali [25] showed that (1) there was a direct effect of asset structure on the firm value. There was no indirect effect of asset structure on the firm value with capital structure as an intervening variable and no direct effect of firm size on the firm value.

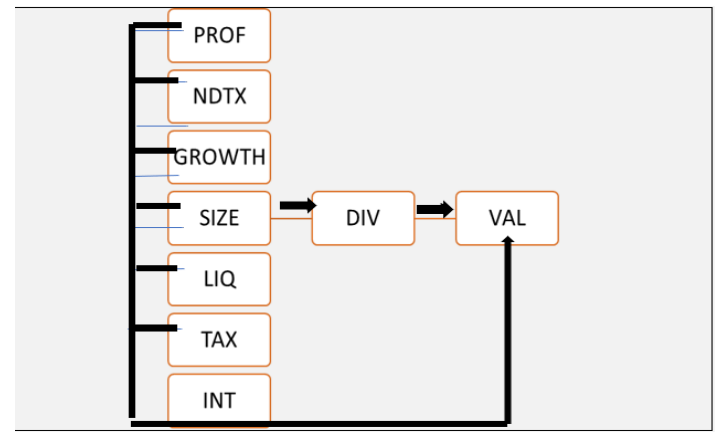

Figure 1: Research Model

\section{METHODOLOGY}

This research is verification research that aims to explain the causal relationship between the variables through hypothesis testing. Data analysis was performed by using multiple regression [12] using panel data. The samples were taken by specifying multiple criteria. The criteria required in this research were: First, these companies are included in the non-financial industries. Second, the companies have been listed on the Capital Market in the selected countries in Southeast Asian Capital Market between 2000-2015. Third, in the period 2000 through 2015, the companies pay a dividend. The study used panel data of companies listed in the capital market in selected countries in Southeast Asia.

This work to look for the factors that determined the dividend policy of selected Southeast Asian countries in non-financial corporate sectors. This study also aims to test the dividend policy mediate characteristics' of the firm to firms value. The equation to test the hypothesis are:

$$
\begin{aligned}
& \text { DIV }=\text { o } 1+\beta 1 \text { PROF }+\beta 2 \text { NDTX }+\beta 3 \text { GROWTH }+ \\
& \beta 4 \text { SIZE }+\beta 5 \text { LIQ }++\beta 6 \text { TAX } \\
& +\beta 7 \text { INT }+ \text { e } \ldots \ldots \ldots \ldots \ldots \ldots \ldots \ldots \ldots \ldots \ldots \ldots \ldots \ldots \ldots \ldots \ldots \ldots \ldots \ldots \ldots \ldots \ldots \ldots \ldots \ldots \ldots \ldots \ldots \ldots \ldots \ldots
\end{aligned}
$$

$\mathrm{VAL}=\sigma 1+\beta 1 \mathrm{PROF}+\beta 2 \mathrm{NDTX}+\beta 3 \mathrm{GROWTH}+$ $\beta 4 \mathrm{SIZE}+\beta 5 \mathrm{LIQ}++\beta 6 \mathrm{TAX}$

$$
+\beta 7 \mathrm{INT}+\beta 8 \mathrm{DIV}+\mathrm{e} .
$$

\begin{tabular}{|c|c|c|c|c|c|c|c|c|}
\hline $\begin{array}{l}\text { Count } \\
\text { ry }\end{array}$ & $\vec{a}$ & 瓷 & $\stackrel{\varrho}{\beth}$ & 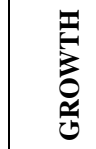 & 돈 & $\sum_{0}^{\frac{\pi}{6}}$ & $\overline{\mathbf{Z}}$ & $\frac{1}{>}$ \\
\hline $\begin{array}{l}\text { Indone } \\
\text { sia }\end{array}$ & b,1021 & 0,0231 & 0,0494 & 1,3540 & $|8,9872|$ & 0,3237 & 0,0931 & 8,74625 \\
\hline $\begin{array}{l}\text { Malays } \\
\text { ia }\end{array}$ & 0,3036 & 0,0195 & 0,0448 & 0,1951 & 5,4442 & 0,1472 & 0,1406 & 5,13448 \\
\hline $\begin{array}{l}\text { Philipi } \\
\text { na }\end{array}$ & 0,2289 & 306,50 & 0,0673 & 1,0086 & 6,6049 & 0,2852 & 138,18 & 6,5025 \\
\hline $\begin{array}{l}\text { Singap } \\
\text { ore }\end{array}$ & 0,4281 & 0,0003 & 0,0900 & 0,2889 & 5,1681 & 0,4033 & 0,0574 & 4,92753 \\
\hline $\begin{array}{l}\text { Thaila } \\
\text { nd }\end{array}$ & 0,7528 & 0,0735 & 0,0558 & 0,1472 & 6,4941 & 0,1537 & 0,0467 & 6,28712 \\
\hline
\end{tabular}

\section{RESULT AND DISCUSSION}

\section{The Descriptive Statistic}

Table 1. The Descriptive Statistic

This table compares the characteristic of Southeast Asian Firms is from 2000 to 2015. DIV is the dividend payout ratio. PROF is net operating after-tax/NOPAT. LIQ is the cash ratio. Growth is the growth of the total asset. SIZE is the total log asset. TAX is the tax rate of the firms. INT is the interest rate of the firms. VAL is a log 
market capitalization. The comparison of firms characteristic in Southeast Asia can be seen in the figure below.

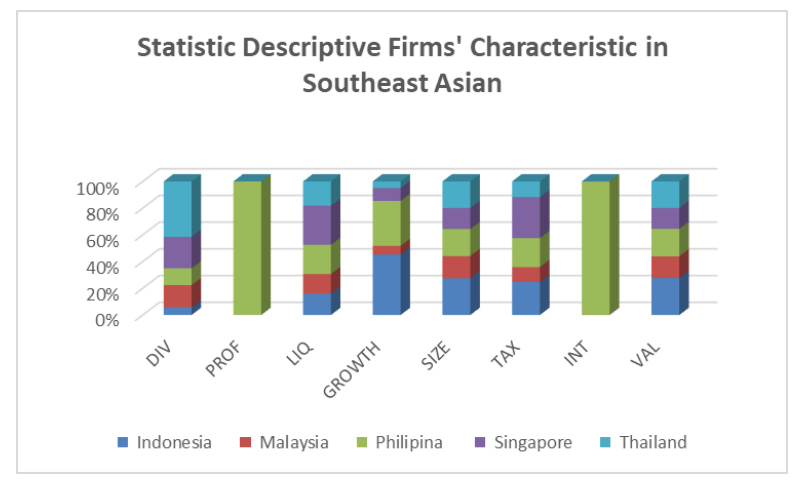

Thailand is the country where their firms pay the most significant dividend payout ratio, and Indonesia considers that the companies pay the smallest dividend ratio in Southeast Asia. Philipina's firms reach the highest profitability among Southeast Asia firms. The liquidity of the firms in Southeast Asian firms, not more than 7\%. The growth rate of Aset in Indonesia and Phillipina is more than $100 \%$. It refers that the profitability of the firms is used to finance the growth's firms.

Table 2. The Determinant of Dividend Policy in the Companies on 5 Countries in Southeast Asia

\begin{tabular}{|l|l|l|l|l|l|}
\hline Countries & Indonesia & Malaysia & Philippines & Singapore & Thailand \\
\hline Variables & \multicolumn{4}{|l}{ Coeff } \\
\hline PROF & -0.000603 & 0.019484 & $-1.91 \mathrm{E}-05$ & 0.051902 & -0.044203 \\
\hline NDTX & -0.000253 & -0.003929 & -0.003307 & -0.008719 & -0.133816 \\
\hline GROWTH & $-1.52 \mathrm{E}-07$ & $-9.95 \mathrm{E}-05$ & -0.000221 & -0.001004 & -0.003164 \\
\hline SIZE & $0.131428 * *$ & 0.107816 & -0.086315 & 0.133205 & 0.445576 \\
\hline LIQ & $-9.78 \mathrm{E}-05$ & -0.056450 & $1.056816 * *$ & 0.185859 & -1.011910 \\
\hline TAX & 0.000122 & 0.000304 & 0.085157 & 0.000268 & 0.051778 \\
\hline INT & -0.023059 & $-9.96 \mathrm{E}-05$ & $-8.90 \mathrm{E}-07$ & 0.007685 & 0.009730 \\
\hline
\end{tabular}
on $10 \%$.

Table 2. Shows the test results of company characteristics that determine companies' dividend policy in 5 countries in Southeast Asia. The results show the company's impact on the dividend policy in five selected countries in Southeast Asia. Profitability has no impact on the dividend policy in the firms in Southeast Asia. The companies that get profit can distribute their profit to the stockholder as a dividend. If the companies need to improve their internal financing, they can retain their profit, increase internal financing, and retain earnings. In this study, profitability is not proven to increase dividend payments. There is a possibility that the profit can be retained as retained earnings or used for debt payments and cannot provide certainty to be paid as dividends.

The companies have a non-debt tax shield derived from depreciation expense and amortization of long-term assets. A company with a sizeable non-debt tax shield means that it has many internal funds that can become internal funds sources. This research showed that five selected countries in Southeast Asia did not impact the dividend policy. The availability of the internal fund did not guarantee that the company would distribute it as a dividend.

A company experiencing growth should affect dividend policy because growing companies generally need funding sources to finance these investments. Internal sources of funding in the company are used to fund these investments so that the internal sources of funding that can be used to pay dividends are lower. In this study, company growth does not significantly affect dividend payments. The company can obtain external sources of funds to fund company growth, so it does not depend on funds' internal sources.

The company's size within the company can be determined based on total assets, sales - the greater the total assets, sales value, and the greater its size. Companies with large total assets indicate that the company has reached the maturity stage where its cash flow is positive. Rachmawati and Triatmoko [23] state that companies with large total assets are considered to have good prospects in a relatively long time. Also, it reflects that the company is relatively more stable and more able to generate profits than companies with small total assets. It can be a positive signal for the market where investors will prefer to invest in large companies because of their healthier financial condition and ability to generate better profits. This research shows that size gives a positive impact on the dividend policy only in Indonesian companies.

In the Philippines, liquidity represents a significant factor affecting dividend payments. Companies that pay cash dividends will depend on the current assets, mostly cash. The companies that have more cash have a more remarkable ability to pay a dividend.

Macroeconomic factors refer to the macroeconomic condition. Right economic conditions showed by the high tax rate and low-interest rate. This research shows macroeconomic factors: tax and interest rate do not affect dividend payments. This study indicated that the right economic conditions did not guarantee the companies in Southeast Asia's five selected countries to pay a dividend.

This research also tested the factors that gave an impact on the firms' value. The factors tested in this research were profitability, non-debt tax shield, company growth, size, liquidity, dividend policy and 
macroeconomic conditions. The result can be seen in Table 3.

Profitability measures the company's ability to generate profits at a certain level of sales, assets and share capital. Based on the signaling theory, one of the manager's obligations is to provide a signal to the owner regarding the company's condition as a manifestation of the manager's responsibility in carrying out company operations, namely by disclosing financial statement information to the owner or interested parties. One of the pieces of information contained in the financial statements is the company's ability to generate profits. The higher profitability growth indicates better company prospects in the future [4]. If the company's profitability increases, it allows the company to finance investment using internal funds available in retained earnings. A high profit will indicate the company's good prospects to trigger investors to increase demand for shares.

Furthermore, the increasing demand for shares will cause the company value also to increase. It indicates that investors consider the level of profitability as one of their rationalizations in making investment decisions. This phenomenon shows that the level of profitability is an incentive for increasing firm value. This situation is in line with research conducted by several previous studies that empirically tested the relationship between profitability and firm value.

The company owns a non-debt tax shield from depreciation and amortization costs of long-term assets of the company. A company with a sizeable non-debt tax shield means that it has many internal sources of funds. There is a possibility that these funds will be used for reinvestment to replace old assets that have expired their economic life. These companies have internal funds invested in profitable investment and will attract investors to invest in these companies. The impact of the price will be increased, and the value of the firm will be increased. There is a positive impact of a non-debt tax shield on the firms' value. A company with a sizeable non-debt tax shield also means that they have many internal sources of funds that can become internal funds sources. Internal sources of funds are those with a low cost of capital. The lower the cost of capital, the higher the firm value. Some companies in Indonesia, Philippine, and Thailand show that the non-debt tax shield positively and significantly affects firm value.
Table 3. The Determinant Southeast Asian Firms Value

\begin{tabular}{|c|c|c|c|c|c|}
\hline $\begin{array}{l}\text { Count } \\
\text { ries }\end{array}$ & $\begin{array}{l}\text { Indones } \\
\text { ia }\end{array}$ & $\begin{array}{l}\text { Malaysi } \\
\text { a }\end{array}$ & $\begin{array}{l}\text { Philippi } \\
\text { nes }\end{array}$ & $\begin{array}{l}\text { Singapo } \\
\text { re }\end{array}$ & $\begin{array}{l}\text { Thailan } \\
\text { d }\end{array}$ \\
\hline \multirow[t]{2}{*}{ Variables } & \multicolumn{5}{|l|}{ Coeff } \\
\hline & Indonesia & Malaysia & $\begin{array}{l}\text { Philippine } \\
\mathrm{s}\end{array}$ & Singapore & Thailand \\
\hline PROF & $\begin{array}{l}0.019375 * \\
* *\end{array}$ & $\begin{array}{l}0.008445 * \\
* *\end{array}$ & $\begin{array}{l}4.53 \mathrm{E}- \\
05^{* * *}\end{array}$ & $\begin{array}{l}- \\
0.015862 * \\
* *\end{array}$ & 0.023825 \\
\hline NDTX & $\begin{array}{l}0.221710^{*} \\
* *\end{array}$ & 0.005186 & $\begin{array}{l}0.014292 * \\
*\end{array}$ & 0.003680 & \begin{tabular}{|l}
$0.544304 *$ \\
$* *$
\end{tabular} \\
\hline GROWTH & $\begin{array}{l}0.003778 * \\
* *\end{array}$ & $8.36 \mathrm{E}-07$ & 0.001573 & $0.000380^{*}$ & $\begin{array}{l}0.002435 * \\
*\end{array}$ \\
\hline SIZE & $\begin{array}{l}0.851952 * \\
* *\end{array}$ & $\begin{array}{l}0.909122 * \\
* *\end{array}$ & $\begin{array}{l}0.218273 * \\
* *\end{array}$ & $\begin{array}{l}0.903772 * \\
* *\end{array}$ & $\begin{array}{l}0.893346 * \\
* *\end{array}$ \\
\hline LIQ & $\begin{array}{l}0.001034 * \\
* *\end{array}$ & $\begin{array}{l}0.716385 * \\
* *\end{array}$ & \begin{tabular}{|l|}
- \\
$0.350478 *$ \\
$*$
\end{tabular} & $\begin{array}{l}0.512057 * \\
* *\end{array}$ & $0.088494 *$ \\
\hline TAX & $\begin{array}{l}0.001156 * \\
* *\end{array}$ & 0.001435 & 0.003620 & $6.63 \mathrm{E}-05$ & 0.000805 \\
\hline INT & $\begin{array}{l}0.234056 * \\
* *\end{array}$ & $\begin{array}{l} \\
0.002077 *\end{array}$ & 2.99E-07 & $\begin{array}{l}- \\
0.008200^{*}\end{array}$ & $\begin{array}{l}0.019553 * \\
* *\end{array}$ \\
\hline DIV & 0.007515 & $0.001067 *$ & $0.015210^{*}$ & 0.000624 & $-1.11 \mathrm{E}-05$ \\
\hline
\end{tabular}

High growth companies will increase company value. Following the theory of Modigliani and Miller, a company will increase in value if it invests. Companies that make investments have grown in their assets. Companies in Indonesia have shown that company growth will increase company value.

The Effect of Company Size on Firm Value Firm size is essential in the financial reporting process. The company's size in this study is measured by looking at how many assets a company has. The assets owned by this company represent the rights and obligations as well as the company's capital. Hesti [14] found evidence that company size had a significant positive effect on company financial performance. Companies with large assets will usually get more attention from the public. It will cause companies to be more careful in their financial reporting. Companies are always expected to try to maintain the stability of their financial performance. This stability attracts investors to own shares in the company. This condition is the cause of the increase in the company's share price in the capital market. Investors have high expectations for large companies. Investors' expectations are in the form of dividends from the company. An increase in demand for company shares will spur an increase in share prices in the capital market. This increase shows that the company is considered to have a more excellent "value." The research of Rizqia et al. [24] stated that company size had a positive effect on firm value. The larger the size of the 51 companies is, the better the company will be in management and management. Based 
on the logic of thinking and the relationship between these variables, firm size has a significant positive effect on firm value. In Southeast Asia, firms refer that size positive significantly give impact to the firms' value

Companies and investors often use liquidity to find out the ability level company in fulfilling its short-term obligations. Short-term obligations such as electricity bills, employee salaries, or debts are past due. Sometimes, some companies cannot pay the debt at the specified time because they do not have sufficient liquid assets to cover the overdue debt. This case will disrupt the relationship between the company and its creditors and distributors because it does not gain customers' trust and reduce its value. The Effect of Liquidity on Firm Value Liquidity is the company's ability to pay off short-term debt-the higher the liquidity, the better its ability to meet its shortterm obligations. High liquidity will make the company safe because it is unlikely that there will be bankruptcy due to not paying its obligations. However, the previous argument is from a short-term perspective. The market's ability to fulfill its short-term obligations will be responded to positively by the market, following the signaling theory concept. With a high liquidity level, the market will trust the company to maintain liquidity, which means the company has a good performance.

Conversely, liquidity that is too high can reduce the company's ability to generate profits because there are many idle funds. Thus, high liquidity will give investors a negative signal that the company cannot utilize existing assets to generate even higher profits. This condition is in line with Nurhayati's [19] research, the higher the liquidity of the company (which is reflected in the ratio of cash to current assets), the more funds available for companies to pay dividends, finance operations and investments so that investors' perceptions of company performance will increase. Liquidity has a significant positive effect on firm value. In Southeast Asia, firms refer that liquidity positively significant give impact to the firms' value

The Effect of Dividend Policy on Company Value Dividend policy is related to company policy regarding how much dividends to be distributed to shareholders and the resulting profits. The number of dividends distributed will affect the stock price of a company. Companies that pay dividends regularly and tend to increase will provide positive investor sentiment. This situation is in line with the signaling theory, which states that the company will guide investors on how management views its prospects. This signal is in the form of information about what management has done to realize the owner's wishes. The explanation above is in line with Dasilas et al. [9] that shows that dividend policy positively affects firm value. In this research, only Malaysia and Phillipina confirm the dividend policy positively impact the firms' value.

Macroeconomic conditions also support the increase in company value. In the right economic conditions, indicated by low-interest rates on debt and taxes, the firms with a high tax rate refer that these companies get profit, give a positive signal to the investor, and increase the firms' value. In conditions of low debt interest rates, it will result in low capital costs and will increase company value. This condition is consistent with companies in Indonesia as well as Malaysia, Singapore and Thailand.

Companies in the Philippines show that dividends significantly affect firm value. Meanwhile, dividends are significantly influenced by company liquidity. The results of this study in the Philippines showed that dividend policy mediated the effect of liquidity on firm value.

\section{CONCLUSION}

In Indonesia, the dividend payment is determined by the company's size, while in the Philippines, it is determined by the condition of the company's liquidity. Companies in five countries consistently show that size is a significant factor affecting firm value. This finding implied that investors would be better off investing in large companies because the value tended to increase and, of course, would impact the welfare of shareholders. This study confirmed that the dividend payment positively impacted the firm value in Malaysia and Philipina. Companies in the Philippines showed that dividends significantly affected firm value. Meanwhile, dividends were significantly influenced by company liquidity. Based on the results of this study in the Philippines, showing dividend policy mediated the effect of liquidity on firm value.

\section{REFERENCES}

[1] AbÃ-o, G., Patxot, C., SÃ $j$ nchez-Romero, M., \& Souto, G. (2017). The welfare state and demographic dividends. Demographic Research, 36, 1453-1490. Retrieved August 26, 2020, from http://www.jstor.org/stable/26332171

[2] Alan D. Crane, Sébastien Michenaud, James P. Weston. (2016). The Effect of Institutional Ownership on Payout Policy: Evidence from Index Thresholds, The Review of Financial Studies, Volume 29, Issue 6, June 2016, Pages 1377-1408, https://doi.org/10.1093/rfs/hhw012

[3] Amelia Sari, Ririn., Anindya Ardiansari (2019). Determinant of Firm Value in Property, Real Estate and Construction Sector 2015-2017. Management Analysis $\begin{array}{llllll}\text { Journal. } & \text { Vol } & 8 & \text { No } & 3 & \text { (2019): }\end{array}$ 10.15294/maj.v9i3.33914.

[4] Annie Koh, Ser-Keng, Brigham and Michael, 8th, 2014, Financial Management Theory \& Practice, South Western

[5] Azhagaiah, R., \& Priya, S. N. (2008). The impact of dividend policy on shareholders' wealth. International Research Journal of Finance and Economics, 20(3), 1450-2887. 
[6] Baker, M., Mendel, B., \& Wurgler, J. (2016). Dividends as Reference Points: A Behavioral Signaling Approach. The Review of Financial Studies, 29(3), 697-738. Retrieved August 26, 2020, from http://www.jstor.org/stable/43866023

[7] Bergbrant, M., \& Kelly, P. (2016). Macroeconomic Expectations and the Size, Value, and Momentum Factors. Financial Management, 45(4), 809-844. Retrieved August 26, 2020, from http://www.jstor.org/stable/26164500

[8] Byoun, S., \& Xu, Z. (2016). Product Market Competition and Financial Decisions During a Financial Crisis. Financial Management, 45(2), 267290. Retrieved August 26, 2020, from http://www.jstor.org/stable/24736493

[9] Dasilas, A. (2009). The ex-dividend day stock price anomaly: evidence from the Greek stock market. Financial Markets and Portfolio Management, 23(1), 59.

[10] Ghosh, S. (2015). How do Banks Influence Firm Capital Structure? Evidence from Indian Data. Indian Economic Review, 50(1), new series, 1-24. Retrieved August 26, 2020, from http://www.jstor.org/stable/43917203

[11] Glendening, M., Khurana, I., \& Wang, W. (2016). The market for corporate control and dividend policies: Cross-country evidence from M\&A laws. Journal of International Business Studies, 47(9), 1106-1134. Retrieved August 26, 2020, from http://www.jstor.org/stable/26170000

[12] Gujarati, Damodar N., Dawn C Porter.2009. Basic Econometric. Fifth Edition. Mc.Graw Hill. New York.

[13] Hashmi, M., Mirza, F., \& Us Sehar, N. (2016). Political Regimes, Internal Funds And Investment Behaviour: An Empirical Analysis Of Manufacturing Sector Firms In Pakistan. Pakistan Economic and Social Review, 54(1), 25-36. doi:10.2307/26616696

[14] Hesti, D. A., \& Syaichu, M. (2010). Analisis Pengaruh Ukuran Perusahaan, Kecukupan Modal, Kualitas Aktiva Produktif (KAP), dan Likuiditas Terhadap Kinerja Keuangan (Studi Pada Bank Umum Syariah di Indonesia Periode 2005-2009) (Doctoral dissertation, UNIVERSITAS DIPONEGORO).

[15] Janicka, M., Pieloch-Babiarz, A., \& Sajnóg, A. (2020). Does Short-Termism Influence the Market Value of Companies? Evidence from EU Countries. Journal of Risk and Financial Management, 13(11), 272.

[16] Jung, J., \& Mun, E. (2016). Bending but Not Breaking?: Foreign Investor Pressure and Dividend Payouts by Japanese Firms. Sociological Forum, 31(3), 663-684. Retrieved August 26, 2020, from http://www.jstor.org/stable/24878788
[17] Leary, M., \& Michaely, R. (2011). Determinants of Dividend Smoothing: Empirical Evidence. The Review of Financial Studies, 24(10), 3197-3249. Retrieved August 26, 2020, from http://www.jstor.org/stable/41301983

[18] Michaely, R., \& Roberts, M. (2012). Corporate Dividend Policies: Lessons from Private Firms. The Review of Financial Studies, 25(3), 711-746. Retrieved August 26, 2020, from http://www.jstor.org/stable/41407845

[19] Nurhayati, M. (2013). Profitabilitas, likuiditas dan ukuran perusahaan pengaruhnya terhadap kebijakan dividen dan nilai perusahaan sektor non jasa. Jurnal Keuangan \& Bisnis Program Studi Magister Manajemen Sekolah Tinggi Ilmu Ekonomi Harapan, 5(2), 144-153.

[20] Pinkowitz, L., Stulz, R., \& Williamson, R. (2016). Do US Firms Hold More Cash than Foreign Firms Do? The Review of Financial Studies, 29(2), 309-348. Retrieved August 26, 2020, from http://www.jstor.org/stable/43866030

[21] Plenborg, T., \& Pimentel, R. (2016). Best Practices in Applying Multiples for Valuation Purposes. The Journal of Private Equity, 19(3), 55-64. Retrieved August 26, 2020, from http://www.jstor.org/stable/44397547.

[22] Prasetia, Ta'dir Eko, Perengkuan Tommy, \& Ivone S. Saerang. (2014). Struktur Modal, Ukuran Perusahaan dan Risiko Perusahaan Terhadap Nilai Perusahaan Otomotif yang Terdaftar di BEI. Jurnal EMBA, 2(2), 879-889.

[23] Rachmawati, A., \& Triatmoko, H. (2007). Analisis faktor-faktor yang mempengaruhi kualitas laba dan nilai perusahaan. Simposium Nasional Akuntansi X, 10(16), 1-26.

[24] Rizqia, Dwita Ayu, Aisjah, Siti, dan Sumiati. 2013. Effect of Managerial Ownership, Financial Leverage, Profitability, Firm Size, and Investment Opportunity on Dividend Policy and Firm Value. Research Journal of Finance and Accounting. Vol. 4 (11).

[25] Setiadharma and Machali, (2017) The Effect of Asset Structure and Firm Size on Firm Value with Capital Structure as Intervening Variable. Journal of Business \& Financial Affairs., 6:4 DOI: 10.4172/21670234.100029872/2167-0234.1000298.

[26] Ucar, E. (2016). Local Culture and Dividends. Financial Management, 45(1), 105-140. Retrieved August 26, 2020, from http://www.jstor.org/stable/247365 